\title{
Acute hypoxic hepatitis as a complication of diabetic ketoacidosis in a boy with newly diagnosed diabetes
}

Ostre niedotlenieniowe zapalenie wątroby jako powikłanie cukrzycowej kwasicy ketonowej u chłopca ze świeżo rozpoznaną cukrzycą

\section{Agnieszka Zubkiewicz-Kucharska, Agnieszka Gorlo, Anna Noczyńska}

Department of Endocrinology and Diabetology for Children and Adolescents, Wroclaw Medical University, Poland

\begin{abstract}
Introduction: Hypoxic hepatitis is characterised by centrilobular liver cell necrosis associated with a rapid and transient increase in serum aminotransferase levels (ALT, AST) in critically ill patients.

The aim of this paper is to present a case report of a paediatric patient with severe ketoacidosis in the course of newly diagnosed diabetes types 1 complicated by hypoxic hepatitis.

Case report: A boy, nearly three years old, was admitted to the hospital with ketoacidosis $\left(\mathrm{pH}-7.058, \mathrm{BE}_{-}-28.3 \mathrm{mmol} / \mathrm{l}, \mathrm{HCO}_{3}-\right.$ $6.3 \mathrm{mmol} / \mathrm{l})$ and glucose level of $434 \mathrm{mg} / \mathrm{dl}(24.1 \mathrm{mmol} / \mathrm{l})$. After 48 hours of treatment with fluids and insulin infusion the serum glucose level and acidosis normalised. On the fourth day of hospitalisation, laboratory tests revealed a rapid increase in AST (to 12955 IU/I) and ALT (to $4328 \mathrm{IU} / \mathrm{I}$ ) concentrations. Increased GGTP level (346 IU/I) and mild coagulation disorders (INR = 0.78) were also observed. In the following days a gradual decrease in transaminase and normalisation of the coagulation system were observed.

Conclusions: Severe diabetic ketoacidosis with significant dehydration and hypovolaemic shock may lead to hypoxic hepatitis, also in small children.

Key words:

diabetic ketoacidosis, hypoxic hepatitis, ischaemic hepatopathy, shock liver.

\section{Streszczenie}

Wprowadzenie: Niedotlenieniowe zapalenie wątroby charakteryzuje się martwicą hepatocytów, związaną z szybkim, ale przemijającym zwiększeniem poziomu aminotransferaz (AST, ALT) w surowicy u krytycznie chorych pacjentów.

Celem niniejszego artykułu jest przedstawienie przypadku dziecka, u którego powikłaniem ciężkiej kwasicy ketonowej w przebiegu świeżo rozpoznanej cukrzycy typu 1 było niedotlenieniowe zapalenie wątroby.

Opis przypadku: Niespełna 3-letni chłopiec został przyjęty do szpitala z kwasicą ketonową (pH - 7,058, BE - 28,3 mmol/l, HCO - 6,3 mmol/l), hiperglikemią $434 \mathrm{mg} / \mathrm{dl}$ (24,1 mmol/l). Po 48 godzinach płynoterapii i insulinoterapii dożylnej, glikemia i gospodarka kwasowo-zasadowa uległy normalizacji. Wykonane 4. dnia hospitalizacji testy laboratoryjne wykazały gwałtowne zwiększenie stężeń AST (do 12955 IU/l) i ALT (do 4328 IU/l). Zaobserwowano również zwiększone stężenie GGTP (346 IU/I) i łagodne zaburzenia krzepnięcia (INR $=0,78)$. W kolejnych dniach obserwowano stopniowy spadek aktywności transaminaz i normalizację układu krzepnięcia.
\end{abstract}

Wnioski: Ciężka cukrzycowa kwasica ketonowa ze znacznym odwodnieniem i wstrząsem hipowolemicznym może prowadzić do niedotlenienia zapalenia wątroby, także u małych dzieci.

Słowa kluczowe:

cukrzycowa kwasica ketonowa, niedotlenieniowe zapalenia wątroby, hepatopatia niedokrwienna, wstrząs wątrobowy.

108 Agnieszka Zubkiewicz-Kucharska
Department of Endocrinology and Diabetology for Children and Adolescents Wroclaw Medical University Chałubińskiego 2A 


\section{Introduction}

Hypoxic hepatitis $(\mathrm{HH})$, also described as "hypoxic hepatopathy", "ischaemic hepatitis", or "shock liver", is characterised by centrilobular hepatocyte necrosis associated with rapid but transient increase of serum aminotransferase levels - either alanine aminotransferase (ALT) or aspartate aminotransferase (AST) - of more than 10 times the upper limit of normal in critically ill patients [1]. The reported incidence rates of $\mathrm{HH}$ vary from $0.2 \%$ of patients admitted to regular beds up to $2 \%$ of those in Intensive Care Units (ICUs) [2].

The pattern of the injury is primary hepatocellular, and cholestasis is absent. The classically proposed pathophysiology of $\mathrm{HH}$ is associated with acute hypoperfusion, when a vital fall in systemic blood pressure (BP) results in a decrease in hepatic perfusion and leads to ischaemic hepatitis. Birrer et al. reported that in $51 \%$ of patients with $\mathrm{HH}$ it was preceded by a hypotensive episode defined by a decrease of mean BP below $80 \mathrm{mmHg}$ for at least 15 minutes [3]. It should be emphasised, however, that $\mathrm{HH}$ may also be a consequence of unreported, transient, and subclinical falls in systemic blood pressure and hepatic perfusion. This may be relevant for patients with chronic heart failure, especially right-heart disease, followed by hepatic venous congestion, where even subtle disturbances in liver circulation may cause hepatic injury [4].

As such, the key pathogenic mechanism of $\mathrm{HH}$ is not only hypotension followed by inadequate oxygen uptake by the hepatocytes, but also venous congestion and reperfusion injury. The diagnosis of acute hypoxic hepatitis is based on three major criteria [1]:

1. Severe and transient increase of serum transaminases levels

2. Haemodynamic signs of cardiac, circulatory, or pulmonary failure

3. Exclusion of other possible causes of liver damage.

More than $90 \%$ cases of $\mathrm{HH}$ are associated with heart failure, both acute and chronic, as well as prolonged periods of hypotension, respiratory failure, and septic toxic shock [1]. Other risk factors include male sex and older age. [3] There is no specific therapy of $\mathrm{HH}$ because it is directed towards the underlying disease, usually of the cardiovascular system $[1,2,5]$.

The literature describes many cases of ischaemic hepatitis in adults, but there are only a few cases of $\mathrm{HH}$ reported in children. To our knowledge, a similar case of $\mathrm{HH}$ as a complication of diabetic ketoacidosis in a paediatric patient was published only once [6].

The aim of this article is to present a case report of a patient with severe ketoacidosis in the course of newly diagnosed diabetes types 1 complicated by hypoxic hepatitis.

\section{Case report}

A male patient, two years and eleven months old, was admitted to hospital with abdominal pain, vomiting, and significant weakness. Before the admission to the Department of Paediatric Endocrinology and Diabetology he had been misdiagnosed as having appendicitis and therefore he had been referred to the Department of Paediatric Surgery. Detailed anamnesis taken there revealed typical symptoms of diabetes (polyuria, polydipsia for at least the past two weeks, weight loss of approximately $1.5 \mathrm{~kg}$ ). Preliminary laboratory tests showed elevated blood glucose level (434 mg/dl, $24.1 \mathrm{mmol} / \mathrm{l})$ and ketoacidosis (pH 7.058, BE [-] $\left.28.3 \mathrm{mmol} / \mathrm{l}, \mathrm{HCO}_{3} 6.3 \mathrm{mmol} / \mathrm{l}\right)$. The boy was diagnosed with type 1 diabetes (T1D) complicated by severe ketoacidosis (DKA). During physical examination the patient presented: tachycardia (160/min), Kussmaul respiration (respiratory rate was 60 breaths per minute), dehydration, pale skin, red throat, tender and painful abdomen, and blood pressure 119/78 $\mathrm{mm} \mathrm{Hg}$.

Liver enzymes, creatinine, and as well as electrolytes were within normal limits (Table I). Glycated haemoglobin was elevated $\left(\mathrm{HbA}_{1 \mathrm{c}} 11.6 \%\right)$, while c-peptide concentration was decreased $(<0.1 \mathrm{ng} / \mathrm{ml})$. DKA treatment was introduced according to ISPAD (International Society for Paediatric and Adolescent Diabetes) guidelines. After two days of intravenous therapy the metabolic disturbances normalised.

T1D diagnosis was confirmed by positive titres of antibodies against islet cells (ICA, titre 1:10, normal range: titre $<1: 10$ ), glutamic acid decarboxylase antibodies (GADA, titre 1:10, normal range: titre $<1: 10)$, as well as islet tyrosine phosphatase 2 (IA2) antibodies (557.0 IU/ml, normal range < $10 \mathrm{lU} / \mathrm{ml}$ ).

Control laboratory tests done on the fourth day of hospitalisation showed markedly increased AST and ALT levels, to $12955 \mathrm{IU} / \mathrm{I}$ and $4328 \mathrm{IU} / \mathrm{I}$, respectively. Synthetic liver function was normal: total protein concentration was $5.2 \mathrm{~g} / \mathrm{dl}$ (N: 3.8-5.4) and albumin level was $3.3 \mathrm{~g} / \mathrm{dl}$ (N: 3.8-5.4). However, mild coagulation disorders were present: prothrombin time (PT) $9 \mathrm{sec}$

Table I. Results of laboratory tests at admission to hospital

\begin{tabular}{lll}
\hline & Results & Normal Ranges \\
\hline $\mathrm{pH}$ & 7.058 & $7.35-7.45$ \\
\hline $\mathrm{pCO}_{2}[\mathrm{mmHg}]$ & 10 & $35-48$ \\
\hline $\mathrm{HCO}_{3}{ }^{-}[\mathrm{mmol} / \mathrm{l}]$ & 6.6 & $22-26$ \\
\hline Base Excess $[\mathrm{mmol} / /]$ & $(-) 28.3$ & $(-2)-(+2)$ \\
\hline Glucose $[\mathrm{mg} / \mathrm{dl}]$ & 434 & $70-104$ \\
\hline $\mathrm{Na}^{+}[\mathrm{mmol} / \mathrm{l}]$ & 134 & $135-146$ \\
\hline $\mathrm{K}^{+}[\mathrm{mmol} / \mathrm{l}]$ & 4.1 & $3.5-5.0$ \\
\hline Creatinine $[\mathrm{mg} / \mathrm{dl}]$ & 0.6 & $0.15-0.61$ \\
\hline AST $[\mathrm{IU} / \mathrm{l}]$ & 12 & $0-45$ \\
\hline ALT $[\mathrm{IU} / \mathrm{l}]$ & 18 & $0-40$ \\
\hline C-reactive protein $[\mathrm{mg} / \mathrm{dll}]$ & 2.6 & $0.2-5$ \\
\hline
\end{tabular}


Table II. Laboratory test results done on the fourth day of the hospitalisation

\begin{tabular}{lll}
\hline & & Normal Ranges \\
\hline AST $[\mathrm{IU} / \mathrm{l}]$ & 12955 & $0-45$ \\
\hline ALT [IU/l] & 4328 & $0-40$ \\
\hline GGTP $[\mathrm{IU} / \mathrm{l}]$ & 346 & $12-64$ \\
\hline Total protein $[\mathrm{g} / \mathrm{dl}]$ & 5.2 & $4.2-7.8$ \\
\hline Albumin $[\mathrm{g} / \mathrm{dl}]$ & 3.3 & $3.8-5.4$ \\
\hline Total bilirubin $[\mathrm{mg} / \mathrm{dl}]$ & 0.6 & $0.2-1.2$ \\
\hline LDH [IU/l] & 545 & $<336$ \\
\hline CPK [IU/l] & 42 & $<154$ \\
\hline PT $[$ sec] & 9 & $10-12$ \\
\hline INR & 0.78 & $0.8-1.3$ \\
\hline APTT [sec] & 22.4 & $26-38$ \\
\hline Fibrinogen [g/l] & 1.88 & $2-45$ \\
\hline
\end{tabular}

(N: 10-12), INR 0.78 (N: 0.8-1.3), activated partial thromboplastin time (APTT) $22 \mathrm{~s}(\mathrm{~N}: 26-38)$, and fibrinogen $1.88 \mathrm{~g} / \mathrm{l}$ $(\mathrm{N}: 2,4,5)$. The laboratory results are presented in Table II. Abdominal ultrasound examination did not show any abnormalities.

The patient was asymptomatic and did not report any complaints. On physical examination signs of liver failure, such as jaundice, ascites, and lower-extremity oedema, were not found. Similarly, he showed no signs of heart failure.

Hepatitis A, B, C, HIV, Epstein-Barr virus, cytomegalovirus, and toxoplasma serology were negative. $\alpha 1$-antitrypsin and ceruloplasmin were normal. The metabolic screens, with the exception ASMA, were also negative (Table III).

In the following few days we observed a gradual decrease of transaminase level (Table IV); however, hepatoprotective treatment was not implemented. Also, ASMA was negative in the control test.

Based on the clinical signs and symptoms, the course of the disease, laboratory tests results, and most of all after excluding any other possible causes of liver damage, acute hypoxic hepatitis was diagnosed.

\section{Discussion}

Diabetic ketoacidosis (DKA) is an acute life-threatening metabolic complication of diabetes characterised by hyperglycaemia, dehydration, acidosis, and electrolyte abnormalities,
Table III. Results of the metabolic screening

\begin{tabular}{lll}
\hline & & Normal Ranges \\
\hline$\alpha 1$ antitrypsin $[\mathrm{g} / \mathrm{l}]$ & 1.02 & $0.9-2.0$ \\
\hline Ceruloplasmin $[\mathrm{g} / \mathrm{l}]$ & 0.38 & $0.2-0.6$ \\
\hline $\begin{array}{l}\text { Anti-LC-1 antibodies } \\
\text { (ELISA) [Ratio] }\end{array}$ & 0.16 & $<1$ \\
\hline $\begin{array}{l}\text { AMA-M2 antibodies } \\
\text { (ELISA) [RU/ml] }\end{array}$ & 4.96 & $<20$ \\
\hline $\begin{array}{l}\text { Anti- LKM-1 antibodies } \\
\text { (ELISA) [RU/ml] }\end{array}$ & 5.57 & $<20$ \\
\hline $\begin{array}{l}\text { Anti- SLA/LP antibodies } \\
\text { (ELISA) [RU/ml] }\end{array}$ & 13.87 & $<20$ \\
\hline $\begin{array}{l}\text { Anti-ASMA anti-smooth } \\
\text { muscle antibodies IIF }\end{array}$ & positive \\
\hline
\end{tabular}

Table IV. Gradual decrease of transaminases and GGTP levels

\begin{tabular}{llll}
\hline Day of treatment & $\begin{array}{l}\text { AST [IU/I] } \\
\text { N: 0-45 }\end{array}$ & $\begin{array}{l}\text { ALT [IU/I] } \\
\text { N: 0-40 }\end{array}$ & $\begin{array}{l}\text { GGTP }[I U / I] \\
\text { N: 12-64 }\end{array}$ \\
\hline 4 & 12955 & 4328 & 346 \\
\hline 6 & 981 & 1795 & - \\
\hline 8 & 208 & 945 & 273 \\
\hline 10 & 83 & 560 & 226 \\
\hline 12 & 54 & 340 & 190 \\
\hline 16 & 37 & 129 & 129 \\
\hline 23 & 30 & 60 & - \\
\hline
\end{tabular}

which result from a deficiency of insulin [7]. DKA is often the first manifestation of previously undiagnosed type 1 diabetes mellitus (DM1), and it is more common in children under four years of age and affects 10/100,000 children [8]. DKA may lead to many complications, such as pancreatitis, prothrombic complications, pulmonary oedema, acute renal failure, severe hypophosphataemia, rhabdomyolysis, highly mortal cerebral oedema, and other rare neurological complications such as cerebral venous thrombosis, dural sinus thrombosis, intracranial haemorrhage, ischaemic stroke [7]. Hyperglycaemia that accompanies diabetic ketoacidosis induces osmotic diuresis, which leads to massive dehydration and in extreme situations to hypovolaemic shock. 
The vascular supply of the liver is extraordinary due to its high metabolic activity. It should be noticed that approximately a quarter of the cardiac output is directed to the liver and it is very sensitive to haemodynamic changes. In order to maintain proper hepatic blood flow, the liver has a unique dual blood supply - via the portal venous system as well as the hepatic artery. Moreover, liver blood flow is somehow sustained by hepatic artery buffer response (HABR) - a mechanism that changes arterial pressure to compensate for alterations in the blood flow, as well as hepatic artery autoregulation, in which a rise in hepatic artery pressure is caused by a decrease in portal vein blood flow. Both mechanisms are mediated by adenosine. The degree of autoregulation, however, is considered to be relatively small. The portal flow that provides the majority of liver circulation is not autoregulated. It is dependent on both mesenteric circulation and the difference between pressures in the portal and hepatic veins [9]. Ischaemic injury may be caused by the reduction of this gradient [2].

The main pathogenic mechanisms of ischaemic hepatitis are hypotension and venous congestion, and usually it results from severe circulatory failure [5]. This may be explained by a "two-hit" mechanism. The first hit, which puts the liver at risk of hypoxaemia, is a consequence of elevated hepatic pressures due to low-flow conditions - a passive congestion, usually arising from right-heart failure. The second hit takes place during acute heart or respiratory failure, leading to hypotension as well as liver ischaemia. In the setting of congestive hepatopathy, the effectiveness of the HABR to mitigate systemic hypotension is reduced [2, 9]. Indeed, cases of $\mathrm{HH}$ are predominantly reported in adult patients as a complication of heart failure. On the other hand, the study published by Denis et al. showed that most of the analysed patients (approximately $50 \%$ of described cases) did not have any cardiac signs [10]. Case reports of this condition in children are few. Probably the main reason for this fact is that $\mathrm{HH}$ can be asymptomatic, as it was in our patient and in the one described by Szypowska et al. [6]. Patients can develop hepatomegaly and hepatojugular reflex is present, but ascites and jaundice are uncommon. Some patients may present gastrointestinal ailments such as nausea, vomiting, diarrhoea, or pain in the right upper quadrant [5]. The presented patient had abdominal pain and was vomiting in first day of hospitalisation, but they were apparently symptoms of
DKA. During the increase of aminotransferases, the patient did not present any symptoms, and biochemical laboratory tests were carried out only as a check-up after DKA treatment.

The typical presentation of $\mathrm{HH}$ includes fulminant increase of aminotransferase concentrations, reaching levels as high as 75-250 times the upper limit of the norm. Such a pattern is considered to be highly correlated with ischaemic liver injury. Moreover, because the concentration of AST is higher in the pericentral area, hepatocyte necrosis in this region due to ischaemia results in greater elevation of AST in comparison to ALT, as was observed in both our patient and Szypowska's patient. The aminotransferase peak levels in both cases were reached within two days of the underlying condition, followed by rapid resolution, indicative of hepatocellular regeneration. Typically for $\mathrm{HH}$, other liver function tests (e.g. serum bilirubin, alkaline phosphatase) remained within the normal limit or were mildly elevated $[2,6]$. Prothrombin time (PT) is longer in $80 \%$ of cases of $\mathrm{HH}$ associated with congestive hepatopathy, but PT may be also decreased [5, 10].

The diagnosis of hypoxic hepatitis was made in the presented patients after excluding other liver diseases, such as viral hepatitis, intoxication, or cholelithiasis, in the setting of hypoperfusion and ischaemia due to dehydration and ketoacidosis in newly diagnosed diabetes. One should remember that liver hypoperfusion in $\mathrm{HH}$ may coincide with other end-organ ischaemia, presented as renal failure in $67 \%$, rhabdomyolysis in $41 \%$, or pancreatitis in $25 \%$ [11]. The mortality rates in $\mathrm{HH}$ are high, reaching approximately $50 \%$ of cases $[2,12]$. The amplitude of aminotransferase levels was traditionally used as an indicator of liver ischaemia. It should be underlined that even the most remarkable elevations in AST and ALT levels due to $\mathrm{HH}$, if the only finding, have little clinical impact and are of low prognostic value [2]. It is the causative condition that determines the prognosis and clinical outcome. Therefore, treatment is directed at the underlying cause of haemodynamic disturbance.

This unusual case demonstrated that severe diabetic ketoacidosis followed by hypovolaemia and metabolic decompensation may lead to liver hypoxia and transient hepatopathy. The lack of pathognomonic signs and symptoms makes hypoxic hepatitis difficult to diagnose. Current guidelines do not include $\mathrm{HH}$ as a complication of DKA in children [7]. 


\section{References}

1. Fuhrmann V, Jäger B, Zubkova A, Drolz A, Hypoxic hepatitis - epidemiology, pathophysiology and clinical management, Wien Klin Wochenschr 2010; 122: 129-139. doi: 10.1007/s00508-010-1357-6

2. Lightsey JM, Rockey DC Current concepts in ischemic hepatitis. Curr Opin Gastroenterol 2017; 33: 158-163. doi: 10.1097/MOG. 0000000000000355.

3. Birrer R, Takuda Y, Takara T. Hypoxic hepatopathy: pathophysiology and prognosis. Intern Med 2007; 46: 1063-1070. doi: 10.2169/ internalmedicine.46.0059

4. Seeto RK, Fenn B, Rockey DC. Ischemic hepatitis: clinical presentation and pathogenesis. Am J Med 2000; 109: 109-113. doi: 10.1016/s0002-9343(00)00461-7

5. Kavoliuniene A, Vaitiekiene A, Cesnaite G, Congestive hepatopathy and hypoxic hepatitis in heart failure: a cardiologist's point of view, Int J Cardiol 2013; 166: 554-558. doi: 10.1016/j.ijcard.2012.05.003

6. Szypowska A, Skórka A, Pańkowska E. Acute hypoxic hepatopathy: diabetic ketoacidosis complication in an infant newly diagnosed with type 1 diabetes mellitus. Endocrinol Diabetol 2008; 14: 249-251.
7. Wolfsdorf JI, Glaser N, Agus M, et al. ISPAD Clinical Practice Consensus Guidelines 2018: Diabetic ketoacidosis and the hyperglycemic hyperosmolar state. Pediatr Diabetes 2018; 19 Suppl 27: 155-177. doi: 10.1111/pedi.12701

8. Lopes LS, Pinheiro PP, Barberena LS, et al. Diabetic ketoacidosis in a pediatric intensive care unit. J Pediatr (Rio J) 2017; 93: 179-184. doi: 10.1016/j.jped.2016.05.008

9. Eipel C, Abshagen K, Vollmar B. Regulation of hepatic blood flow: the hepatic arterial buffer response revisited. World J Gastroenterol 2010; 16: 6046-6057. doi: 10.3748/wjg.v16.i48.6046

10. Denis C, De Kerguennec C, Bernuau J, et al. Acute hypoxic hepatitis ('liver shock'): still a frequently overlooked cardiological diagnosis. Eur J Heart Fail 2004; 6: 561-565. doi: 10.1016/j.ejheart.2003.12.008

11. Raurich JM, Llompart-Pou JA, Ferreruela M, et al. Hypoxic hepatitis in critically ill patients: incidence, etiology and risk factors for mortality. J Anesth 2011; 25: 50-56. doi: 10.1007/s00540-010-1058-3

12. Aboelsoud MM, Javaid Al, Al-Qadi MO, et al. Hypoxic hepatitis - its biochemical profile, causes and risk factors of mortality in critically ill patients: A cohort study of 565 patients. J Crit Care 2017; 41: 9-15. doi: 10.1016/j.jcrc.2017.04.040 